This is the author's Post-print version (final draft post-refereeing as accepted for publication by the journal). The definitive, peer-reviewed and edited version of this article is published as: Bolt G., van Kempen R., van Ham M. (2008) Minority ethnic groups in the Dutch housing market: spatial segregation, relocation dynamics and housing policy. Urban Studies 45(7), 1359-1384.

http://dx.doi.org/10.1177/0042098008090678

\title{
Minority ethnic groups on the Dutch housing market: spatial segregation, relocation dynamics and housing policy
}

\author{
Gideon Bolt*, Ronald van Kempen*and Maarten van Ham**
}

* $\quad$ Gideon Bolt and Ronald van Kempen are in the Urban and Regional Research Centre Utrecht, Faculty of Geosciences, Utrecht University, PO Box 80.115, 3508 TC Utrecht, The Netherlands. Fax: 3130 2532037. E-mails: g.bolt@geo.uu.nl and r.vankempen@ geo.uu.nl. ** Maarten van Ham is in the Centre for Housing Research, the University of St Andrews, School of Geography and Geosciences, Irvine Building, North Street, St Andrews, Fife, KY16 9AL, Scotland, UK. Fax: 1334 463949. E-mail: maarten.vanham@st-andrews.ac.uk.

\begin{abstract}
Ethnic segregation is consolidated by differences between ethnic groups with regard to their moving decision. Using unique registration data on population flows between neighbourhoods we show that native Dutch living in neighbourhoods where ethnic minorities are overrepresented are more likely to move than minority ethnic residents. Moreover, they move much more often to 'white' neighbourhoods. Urban policies in the Netherlands focus on countering this tendency of segregation, but are based on simplified assumptions with regard to the causes of residential segregation. Next to that, the optimism about the positive effects of social mix is hardly substantiated by empirical research.
\end{abstract}

\section{Introduction}

Much of the academic research on residential segregation emphasises the negative effects of disadvantageous influence of living in a spatial concentration of deprivation (Massey and Denton, 1993; Wilson, 1987). The general idea is that living in a deprived district can have negative consequences for the social position and social mobility of the residents, because they lack contacts with relevant people and institutions or they have too many "wrong" contacts Massey and Fong, 1990; South and Crowder, 1998; South, Crowder and Chavez, 2005). These negative consequences are mainly problematic for people who are not in a position to move away from disadvantageous neighbourhoods. Research has shown that deprivation in a neighbourhood can have many negative consequences, such as: the occurrence of teenage pregnancies (Anderson, 1999); low socioeconomic position (Galster, Metzger and Waite, 1999); school dropout (Overman, 2002); poor educational achievement; and retarded child development (Crane, 1991; Duncan, Brooks-Gunn and 
Klebanov, 1994); limited transfer from unemployment to work (Van der Klaauw and Ours, 2003); deviant behaviour (Friedrichs and Blasius, 2003); social exclusion (Buck, 2001); victimization (Sampson, Raudenbush and Earls, 1997); and poor access to the labour market (Ihlanfeldt and Sjoquist, 1998).

In the literature on ethnic segregation, however, there is also attention for possible positive effects of ethnic segregation. Spatial concentrations can have an important expressive function, assisting with the maintenance of a groups' cultural traditions (Dunn, 1998). Next to that, living in an ethnic enclave makes it easier to maintain ethnic networks, through which people are able to derive benefits from each other and offer support to one another (Bolt et al., 1998). Moreover, ethnic neighbourhoods may function as a safe haven in a hostile environment (Boal, 1976) and they may provide alternative channels for social mobility (Portes \& Zhou, 1993).

While there is attention for positive as well as negative effects of ethnic concentration in the literature, the focus in policy circles is almost exclusively negative. That is the reason why urban policies in the Netherlands are, like in an increasing number of other Western European countries, directed at countering residential segregation and spatial concentration of low-income households and minority ethnic groups (Kleinhans, 2004; Musterd, 2003; Veldboer et al., 2002). The Dutch government beliefs that the concentration of ethnic minorities in certain urban neighbourhoods hampers their integration and participation in society. In the Yearly Memorandum on Integration Policy (Ministerie van Justitie, 2005, p. 19, own translation) it is stated that "...Concentration is especially disadvantageous for integration because it results in an accumulation of social problems which may eventuate in a state of affairs that is very hard to handle (...). Concentration is also disadvantageous because it makes the ethnic dividing lines more visible in a more concentrated way. That harms the image of ethnic minorities (...). Finally, concentration is particularly disadvantageous for the possibilities for meeting and contacts between persons from different origin groups (...) the diminishing contacts with native Dutch indirectly influence the social chances of ethnic minorities".

The most important measure to counter segregation is to create more social mix by means of differentiation of the housing stock. The aim of this paper is to critically examine the foundations of the Dutch anti-segregation policy by answering two questions. First, to what extent are the supposed positive effects of social and ethnic mixing found in empirical research? This question will be answered on the basis of a literature review. Second, to what extent does urban restructuring really address the causes of ethnic segregation? The premise that underlies housing differentiation policy is that ethnic segregation is merely a reflection of socio-economic segregation, which on its turn is the outcome of the spatial dispersion of affordable housing. In order to obtain a better understanding of segregation, we consider relocation behaviour between neighbourhoods and districts. In practice, that is rarely done, because although researchers usually have data available on the composition of neighbourhoods, they do not have data on the relocation behaviour of individuals or households. We have used for our purpose unique data from Statistics Netherlands (CBS) for the Gemeentelijke Basis Administration [Municipal Basis Administration] (GBA). We have sought to verify whether immigrants mainly move to immigrant neighbourhoods and native Dutch to indigenous neighbourhoods. If that is the case, then segregation in Dutch cities cannot be expected to diminish in the short term. One the basis of an analysis of two large scale surveys in the Netherlands (The Housing Demand Survey 2002 and the Housing Research Netherlands 
survey 2006), we try to establish to what extent differences in spatial behaviour between minority ethnic groups can be attributed to differences in socio-economic and other factors.

Before answering the questions formulated above, we will give a brief overview of the academic literature on the causes of ethnic segregation. Subsequently, we will give a description of the level of segregation in Dutch cities. We concentrate on the four big cities (Amsterdam, Rotterdam, The Hague and Utrecht), because that is still where relatively the most immigrants live.

\section{How can segregation processes be explained?}

The spatial segregation of ethnic groups has been an essential topic in urban geography and urban sociology for more than 80 years. In the 1920s, researchers in the Chicago School were pioneers in this field (see, for example, Burgess, 1925; Park, 1925). They described the spatial patterns of different immigrant groups in the city of Chicago and were particularly interested in the dynamics in these patterns. Their descriptions of the dynamics featured the terms invasion, succession, and dominance derived from biology. The inflow of a new group of residents into a neighbourhood is, according to Park (1925), comparable to the invasion by a new species of an existing ecosystem. As a consequence of the invasion, other species no longer feel at ease and seek their refuge elsewhere. The same processes apply with homo sapiens: people leave their residential environment following an inflow of a new population group. As a result, more dwellings become vacant for the members of the new group. There is then evidence of succession: one population group is succeeded by another. Eventually, dominance can be observed: one group replaces the other (for the most part) and comes to dominate the district. The processes of invasion-succession-dominance are also readily observable in Dutch cities. We return to this matter later.

The research of the Chicago School was for the most part just descriptive in nature so that it remained unclear what processes brought about the population dynamics in districts and the consequent segregation patterns. Nevertheless, the spatial assimilation model based on the ideas of the Chicago School has retained a dominant position in segregation research, particularly in the United States. This theory was not developed in the time of the Chicago School, but was formulated later by Massey (1985) to some extent on the basis of the (frequently conflicting) publications of the social-ecologists.

In brief, according to the spatial assimilation model, the segregation of ethnic groups declines as their length of residence increases (Lieberson, 1961). The mechanisms that bring about the dispersion of ethnic groups are acculturation and socioeconomic mobility (Charles, 2003; Logan and Alba, 1993; Massey, 1985). Acculturation is the gradual acquisition of the language, norms, and values of the host community (Gordon, 1964). The greater the extent to which in the course of time immigrants integrate with the host community, the less is their need to live in the proximity of their own group. In addition, in the course of time more immigrants will climb the social ladder and will also want to benefit from their newly-acquired status by moving into a qualitatively better neighbourhood. That usually entails moving to a neighbourhood where more native Dutch

live. In a geographic sense, spatial assimilation is accompanied by a process of 
decentralization. Enclaves surrounding the inner city are exchanged for more mixed neighbourhoods in the suburbs and at the edge of the city (Burgess, 1925).

Of the three determinants of segregation (length of residence, acculturation, and socioeconomic status) the last named has been the most popular object of research. Many studies are centred on the question of the extent to which ethnic segregation can be accounted for by socioeconomic differences. Because the segregation of immigrants by no means invariably declines in the course of time and furthermore can only be explained by differences in socioeconomic position to a limited extent, two alternatives for the spatial assimilation model have been put forward. The cultural preference approach assumes that the preference for living in a neighbourhood where one's own ethnic group is strongly represented persists, even if socioeconomic and cultural differences decline. Research undertaken in Asian groups (see, for example, Bowes, Dar and Sim, 2002; Robinson, 1981) shows that the preference for living in Asian districts is still very strong. In fact, it transpires from American research in particular that the preference for living in a district where one's own group dominates is by far the strongest among native whites (Charles, 2003; Emerson et al, 2001; Ilhanfeldt \& Scafidi, 2004). The preference of ethnic groups extends much more often to mixed residential areas. In the event, relatively few people succeed in realizing their preference for an ethnically mixed district. Schelling (1969) has shown that even relatively small differences in terms of preferences with respect to the population composition of a neighbourhood can lead to strongly segregated residential neighbourhoods (see also Clark, 1991). Suppose that, in a completely white neighbourhood, a number of black people who have no problem with living in a white neighbourhood move in. For a few white people, that influx acts as the trigger for them to move to another neighbourhood. The dwellings that become available are also attractive to black people who would like to live in a predominantly white neighbourhood. If the number of black residents then rises, more white people will feel that the limit of the maximum acceptable percentage of black residents has been exceeded and they will also move out. The end result is then a neighbourhood which has completely changed in colour in a relatively short time.

An alternative to the spatial assimilation model is the ethnic stratification model (Logan and Alba, 1993; South and Crowder, 1998). This features the role of discrimination on the housing market, which makes it difficult even for immigrants with a good economic position to acquire a dwelling in a neighbourhood associated with high socioeconomic status. There have indeed been many studies in both the US and in Western Europe that have revealed discriminatory practices by actors of all kinds on the housing market. We can think of mortgage providers (Aalbers, 2005; Galster, 1999), estate agents (Philips and Karn, 1992, Yinger, 1999), (social) landlords (Aelbers, Smeets and Van der Ven, 1991; Philips, 1998), local (Musterd et al., 1996) and national government institutions (Giffinger, 1998).

Apart from the barriers on the housing market that specifically confront immigrants, it is also important for the explanation of segregation and the underlying relocation behaviour to consider the restrictions that are imposed from the supply side on a household's freedom of choice. Two issues are of importance here: the accessibility and the availability of dwellings and neighbourhoods. By accessibility we refer to the question of whether households can afford a dwelling, for example. By availability, we assess whether particular types of dwelling are available or within reach in terms of size, price, owner-occupied or rented, or quality (Özüekren and Van Kempen, 2003). Access to 
particular segments of the housing market for particular groups is determined by specific institutions and the people who function within them. When a local authority decides that people whose income is below a certain limit are no longer entitled to look for a dwelling in the city, they are directed to other areas.

Policy that is aimed at the demolition or renovation of inexpensive dwellings and their replacement by dwellings in a higher price class leads to the restriction of the choice opportunities of low-income households. In various European countries, including the Netherlands, policy in the big cities is currently directed to the creation of more diversification in the housing stock and thereby also in the population (see, for example, Van Kempen and Priemus, 2002). This policy is usually aimed at the creation of diversification with respect to income within a neighbourhood and not explicitly to a mixture with respect to ethnicity. But the usual effect of creating more expensive dwellings in a district is that ethnic groups have to look elsewhere for a home, because they cannot afford the more expensive dwellings on their low incomes.

The direct and indirect influence of macro-developments is increasingly acknowledged in the explanation of spatial segregation and concentration. These developments operate on spatial scale levels that are above those of the individual city. Economic developments on a world scale determine to an important extent the financial room for manoeuvre in a local context of individuals, market parties, and the government authority. Increasing employment offers more households more perspectives on the housing market. Demographic developments on different spatial scale levels are of great importance in the competition between different groups on the housing market: more immigration in an area means in principle more competition. Social-cultural developments are of importance for the demands people put on their dwelling and residential environment (Van Kempen and Özüekren, 1998).

It is evident that the spatial segregation and concentration of immigrants is determined by a large number of factors and developments. On the one hand are the variables which relate to the wishes of households and individuals, and on the other hand are their opportunities and limitations. The opportunities are determined by an interaction between the means of households and individuals and the supply-side factors. On the supply side, the availability and accessibility of dwellings have important roles. Developments in segregation and the concentration of ethnic groups can be explained to an important extent with the help of these factors and the developments within them.

\section{Spatial segregation of immigrants in the Netherlands}

How can the current segregation of immigrants in Dutch cities be characterized? What developments can be identified? And how can these developments be explained? In this section we first pay attention to the overrepresentation of immigrants in the big cities. We then consider the development of segregation within the four largest cities. Is segregation increasing or decreasing with respect to the rest of the country? Which neighbourhoods are affected by the strongest increase in the share of immigrants?

We restrict our description of segregation in the Netherlands to the four largest immigrant groups: Turks (358 thousand), Surinamese (328 thousand), Moroccans (315 thousand) and Antilleans (including Arubans: 130 thousand). Together with the remaining 
non-western immigrants (431 thousand), they have a share of the total Dutch population of 10.4 percent (SCP/WODC/CBS, 2005).

\section{Overrepresentation in the four big cities}

The four largest immigrant groups are strongly concentrated in the big cities. While just 13 percent of the Dutch population live in Amsterdam, Rotterdam, Utrecht or The Hague, more than half the Surinamese and almost half the Moroccans do so (table 1). More than a third of the Turks and Antilleans live in one of the four big cities. Since the 1990s the significance of the four big cities has increased for the Antilleans to a striking extent (Bolt and Van Kempen, 2000). That comes about because relatively many recent immigrants settle in the big cities (table 1). For the three largest groups of immigrants the significance of the four big cities has in fact declined. That decrease applies most strongly to the Surinamese, 57 percent of whom lived in 1997 in one of the four big cities. The decreasing significance for immigrants of the four big cities relates to the increase in migration out of the city on the one hand and on the other to the reduced power of attraction of the four big cities on immigrants. With respect to the last factor, it can be seen from table 1 that Turkish, Moroccan, and Surinamese immigrants are still (somewhat) more strongly attracted to the big cities than are the members of these ethnic communities already present. On the other hand immigrants settle less frequently in the big cities than previously was the case. In 1997, 45 percent of the Turkish, 53 percent of the Moroccan, and 63 percent of the Surinamese immigrants arrived and settled in one of the four big cities (Van Huis and Nicolaas, 2000).

$<$ Table 1 around here >

The decreasing importance of the four big cities for the accommodation of the three largest immigrant groups is mainly the result of the increase in suburbanisation. In Amsterdam half the suburbanisation flow in 2003 consisted of immigrants, compared with a third in 1994 (De Groot, 2004). In Rotterdam the percentage of non-western migrants in the suburbanisation flow rose from 20 percent in 1992 to 40 percent in 2002 (Burgers and Van der Lugt, 2005). Suburbanisation is particularly high among Surinamese, who in that respect scarcely differ from the native Dutch. The spatial assimilation model therefore seems to be appropriate to the Surinamese. The suburbanisation of Turks and Moroccans lags behind, although in the last few years the Turks in particular seem to have begun to catch up. In any event, the suburbanisation of immigrants is in the direction of the larger municipalities in the region (Almere, Zaandam, Purmerend, Schiedam), which are now less popular with the native Dutch.

\section{Segregation in the four big cities}

Dozens of segregation-indices have been developed in an attempt to put a figure on the extent of segregation (Massey and Denton, 1988). We focus on the segregation-index (table 2), because that is the most frequently used both nationally and internationally and so facilitates comparison with other cities. In any event, these comparisons must be treated with caution, however. The segregation-index is influenced by the manner in which the neighbourhood boundaries are drawn and also by the average size of the neighbourhoods: 
the smaller the neighbourhood, the higher the index turns out to be. Next to that, the index is limited to dichotomies and the expected value is greater than zero, as it is unlikely that the distributions of ethnic groups would be exactly identical even if ethnicity was irrelevant. Finally, the segregation-index does not take account of the spatial relationships between neighbourhoods. In other words, the degree in which ethnic neighbourhoods adjoin one another or not does not have any influence on the magnitude of the segregation-index (White, 1983).

The segregation-index runs from 0 (proportionate distribution over the city) to 100 (complete segregation).

The value of a segregation-index can be interpreted as the percentage of a group that would have to move out to obtain an even distribution over the municipality proportionate to that of the rest of the population.

Comparison of the segregation-indices between years and between cities (table 2) reveals a completely consistent pattern with respect to the differences between the four ethnic groups. Turks and Moroccans invariably score much higher than do Surinamese and Antilleans. In most cases there are no substantial differences between Turks and Moroccans or between Surinamese and Antilleans.

$<$ Table 2 around here $>$

If the cities are compared, it is evident that up to the end of the 1990s a clear distinction could be drawn with respect to the segregation patterns in Rotterdam and The Hague on the one hand and in Amsterdam and Utrecht on the other. The segregation-indices in The Hague and Rotterdam were higher than in the other cities (except for the Antilleans, who in Amsterdam have the most segregated living accommodation), largely because few immigrants have succeeded in moving to the (post-war) housing estates at the edge of the city, as there was less vacancies in these neighbourhoods, because they enjoyed considerable popularity among the Dutch residents. Many immigrants continued for a long time to be directed to urban renewal areas. There, many suitable dwellings for (large) families were to be found, because relatively many large dwellings were restored in the urban renewal process (Bolt and Van Kempen, 2000).

In the course of the 1990s the flow of immigrants into post-war districts became steady and that led to a decrease in segregation. In The Hague the decrease in segregation more or less came to a halt, so that this is still the most segregated big city of the Netherlands. In Rotterdam on the other hand the segregation level hardly differed from that in Amsterdam and Utrecht, where the segregation in the last few years has remained reasonably stable. In these two last-named cities the shift from the old districts to the postwar districts took hold earlier than in The Hague and Rotterdam, so that immigrants were spread relatively more evenly over the city. That was brought about on the one hand through particular districts becoming at a given moment less popular with the native Dutch, so that relatively many large affordable dwellings became available; and on the other hand, there was considerable competition in the old districts round the city centre, more than in Rotterdam or Den Haag, with young highly-educated singles or couples (Bolt and Van Kempen, 2000). 
In comparison with the big cities, the segregation-index in medium-sized cities $(>100,000$ inhabitants) is in general lower. In the smaller cities the segregation is a little lower still. That is in line with the idea, dating from the time of the Chicago School, that the larger the city and the greater the share of immigrants, the greater is the segregation (Massey, 1985). This hypothesis was recently reconfirmed in a large-scale study in the US (Wilkes and Iceland, 2004).

\section{Countering segregation: urban policies in the Netherlands}

The present Dutch urban policy aims to reduce the concentration of low-income households in urban neighbourhoods and to combat the negative effects of the concentration of minority ethnic groups on their integration (Ministerie van Justitie, 2005). The issue of countering segregation has already been (back) on the agenda since the second half of the 1990s, but the policy focus used to be mainly on income segregation. In line with changes in the Dutch political climate in the last few years, however, the concern with the concentration of poverty in certain neighbourhoods has been given way to the anxiety about ethnic concentration. At the same time, the measures that are taken to counter segregation are not explicitly focused on ethnicity, partly due to antidiscrimination legislation. There are three instruments that are brought into action to combat segregation (Ministry of Justice, 2005, p. 45):

1) Differentiation of the housing stock in 'concentration neighbourhoods';

2) Regulation of the influx of low-income groups into certain 'concentration neighbourhoods';

3) Extension of the housing opportunities for low-income groups outside the city.

Whereas the first two measures lead to the reduction of choice opportunities of lowincome households, the third measure aims to enhance their choice (Bolt et al., 2002). Unfortunately, this measure has been given not much priority by the national government. In fact, the ruling parties in parliament have voted against a bill that provided for binding regional agreements in which suburban municipalities are - if necessary - forced to play a larger role in providing housing for low-income groups.

The regulation of the influx of low-income groups is the most heavily debated antisegregation measure in the Netherlands. Following the initiative of the city of Rotterdam, a national law has been passed, which gives cities the opportunity to ask permission to the Ministry of Housing to implement a divergent allocation policy for certain deprived parts of the cities. Persons from outside the city without a paid job (except students and retired persons) are not granted a residence permit in these designated neighbourhoods. The realization of this so-called 'Rotterdam-law' can be attributed to the electoral triumph in 2001 of anti-immigrant party Leefbaar Rotterdam. While the trigger for the Rotterdamlaw was the increasing ethnic concentration in Rotterdam, the law is not directly addressing the minority ethnic groups (Bolt, 2004). Indirectly, however, they are affected disproportionately more than the established population (Kleinhans, 2004).

At first sight, it may seem to be striking that it was Rotterdam that initiated this anti-segregation law, while it is the only city of the big four where the level of segregation is declining. However, it should be taken into consideration that, despite the decline in segregation, the proportion of minority ethnic groups in the population of Rotterdam has 
risen. Next to that, the declining segregation was brought about by increasing numbers of minority ethnic households in post-war neighbourhoods, which meant that many native inhabitants of Rotterdam were confronted with a change in the ethnic composition in their neighbourhood. It was especially in these neighbourhoods where Leefbaar Rotterdam captured a lot of votes.

The actual effect of the 'Rotterdam-law' on segregation is up to now very limited. It has been estimated that it will only prevent a few hundred jobless people from outside Rotterdam to move into the designated areas. Nevertheless, the law can be criticized for several reasons (Bolt, 2004). First of all, implicitly people without a job (amongst which a high proportion of members of minority ethnic groups) are held responsible for the problems in concentration neighbourhoods. Instead of creating opportunities for social mobility, urban policy is aimed a excluding people without a job. Next to that, it should be questioned if the designated neighbourhoods will benefit from this policy. The fact that a neighbourhood is picked out as a 'hot spot' (in terms of the Rotterdam-law) is most likely to harm its reputation.

By far, the most substantial measure to counter segregation is the differentiation of the housing stock in deprived neighbourhoods. In 1997, the Memorandum on Urban Renewal [Nota Stedelijke Vernieuwing] was published with the aim to help bring an end to the increasing concentrations of low-income households in, especially, the post-WWII social housing estates. The objective of the Memorandum was clearly stated as achieving a mixed population: "Although there are no extreme concentrations of vulnerable groups, there are certain neighbourhoods where problems prevail. There is a chance that this will lead to mutually reinforcing processes of dilapidation in parts of the cities. In several neighbourhoods liveability and safety are under pressure ... In some neighbourhoods where one-sidedness can occur or already dominates, increasing the diversity of the housing stock ... can facilitate physical, social and cultural improvement of living and working environments in these neighbourhoods." Urban restructuring became the key word: a large number of social rented dwellings in areas that were dominated by this housing segment had to be demolished or upgraded, in order to make place for more expensive, often owner-occupied dwellings. In this way concentrations of low-income households could be countered, and a more mixed population could be strived for (Ministerie VROM, 1997).

While "one-sidedness" of a neighbourhood population was initially mainly defined in terms of income, the negative effects of ethnic segregation came more and more to the fore, partly as a consequence of the election campaign of the late politician Pim Fortuyn, who was murdered in May 2002 (Kleinhans, 2004).

As is the case with the Rotterdam-law, urban restructuring is not directly aimed at reducing ethnic segregation, but the assumption is, that socio-economic segregation is the main determinant of ethnic segregation (cf. Andersson, 2006) for the Swedish case). Consequently a reduction of socio-economic segregation is expected to lead automatically to a reduction of ethnic segregation.

Most critics of urban restructuring comment on the assumption that housing differentiation will bring about positive social effects in the neighbourhood. Low-income groups (and the members of minority ethnic groups amongst them) are expected to benefit from social mix in several ways (Joseph et al., 2007; Kleinhans, 2004; Uitermark, 2003): 1) Social interaction between residents of different background leads to social mobility; 2) Higher incomes and homeowners may act as positive role models for lower incomes; 3) 
Social mix leads to an increasing social control; 4) the presences of affluent residents contributes to more collective action and will therefore have a positive effect on the quality of (public) services in the neighbourhood.

For the discussion on the effect of mixing on integration of ethnic minorities the first two benefits that are mentioned are most relevant. There is, however, not much evidence on the claim that higher incomes act as a role model for lower incomes (and the members of minority ethnic groups amongst them). Asking residents whether owners or people with a higher social status act as role models is likely to be considered paternalistic or even insulting (Rosenbaum et al., 1998). There is no evidence that lower-income groups adhere less to "mainstream" values (Joseph et al. 2007) and Dekker and Bolt (2005) even found that members of minority ethnic groups in two mixed Dutch neighbourhoods are less tolerant toward deviant behaviour than the native population.

There is much more research on the claim that social mix provides opportunities for social interaction between residents of different income levels and ethnic backgrounds. In this way residents may accumulate more social capital, which is expected to have a positive impact on their social mobility. However, several studies in the Netherlands (e.g. Dekker \& Bolt, 2005; Van Beckhoven \& Van Kempen, 2003), the UK (e.g. Atkinson \& Kintrea, 2000; Bramley \& Morgan, 2003), and the US (e.g. Gans 1961; Brophy \& Smith, 1997) have shown that social interactions between different categories (in terms of tenure, socio-economic status or ethnicity) do not automatically occur in practice. The general picture is that different groups of people in the neighbourhoods live alongside each other, not together. There are, however, indications that social interactions between income groups occur when there is a moderate degree of income heterogeneity (Brophy \& Smith, 1997; Rosenbaum et al., 1998).

While social mix is not likely to engender more bridging capital for minority ethnic groups, there is possibly a negative effect on bonding capital. Those who have to move because of the restructuring process might end up in different kinds of areas in the city, which may prohibit daily social contacts between people who used to have good contacts within the neighbourhood. Those who can stay run the serious risk of a declining number of social contacts, on the one hand because some neighbours, friends and acquaintances have to move, on the other hand, because the people that are entering are probably "different kinds of people". Seen along this line, urban restructuring is not very helpful for sustaining ethnic communities (Crump, 2002).

Apart from the academic scepticism with regard to the positive social effects of social mix that are claimed by policymakers, they are also serious doubts whether urban restructuring is an effective mean to combat segregation. Of course, demolition and upgrading of the housing stock will bring about a decrease of low-income (minority ethnic) households in certain neighbourhoods, but these households have to move to other places in the city, especially towards neighbourhoods where affordable housing is still available. There is a large "risk", therefore, that the idea of creating more socio-economic mixed communities in one area engenders socio-cultural concentrations in another area, because only in those areas unaffected by the policy of urban restructuring affordable housing is still available. (Crump, 2002; Van Kempen \& Priemus, 2002). Musterd (2003) adds to that criticism that urban restructuring does not address the causes of segregation. Differentiation of the housing stock cannot change the tendency that people choose to associate themselves with like minded people (Musterd, 2003). In the next section, we will further look further into the role of group-specific neighbourhood choices. 


\section{Segregation and relocations: who moves where?}

Uunk and Dominguez Martinez (2002) have analysed relocation flows of native Dutch and ethnic groups between different types of district in 1999. Using more recent data, we have repeated their calculations and refined them on two points. First, we distinguish six different sub groups within the group of immigrants. In contrast with Uunk and Dominguez Martinez, this distinction makes it possible to differentiate between western and non-western immigrants and focus on the non-western immigrants. Second, we look specifically at the inflow, outflow, and through-flow of residents in districts of the four big cities and we have investigated who leaves the city and where people coming from outside the city settle. Through this refinement, we could obtain more insight into the extent to which different groups move between, into or out of concentration neighbourhoods.

For the purposes of the analysis we obtained from Statistics Netherlands (CBS) a matrix with all the relocation activity between the almost 4000 Dutch 4-unit postcode areas. The matrix, originating from the Gemeentelijke Basis Administratie [Municipal Basic Administration] (GBA), covers all 1,595,926 individuals who relocated in 2002 classified according to their place of origin. Seven areas of origin are distinguished (CBS definitions): the Netherlands (native Dutch); Surinam; Dutch Antilles/Aruba; Turkey; Morocco; Western countries; other non-western countries. For the analysis, we selected and classified all house moving within, between, from, and to districts in Amsterdam, Rotterdam, The Hague, and Utrecht. We classified the city districts on the basis of the percentage of non-western residents living there (see also Latten, Nicolaas and Wittebrood, 2005). We distinguished the following categories: 0-5 percent, 5-10 percent, 10-25 percent, 25-50 percent, and 50-100 percent of non-western residents.

$<$ Table 3 around here >

Table 3 shows the distribution of the urban population according to the five separate district categories and the seven areas of origin. In total, on 1 January 2002 more than two million people lived in the four big cities. Just three percent of these people $(60,834)$ lived in districts with less than five percent non-western residents while in the whole of the Netherlands almost 48 percent of the total population live in districts with $0-5$ percent non-western residents. In the table it can be seen that native Dutch and western immigrants are approximately equally distributed over the urban districts. The other groups are concentrated to a substantial extent in concentration neighbourhoods. That applies most strongly to the Turks and Moroccans.

Inflow into the city from the rest of the Netherlands and from abroad

Native Dutch who come from outside the four big cities (but still from the Netherlands) settle mostly in districts with between 5 and 50 percent non-western residents (table 4). Surinamese, Antilleans, Turks, and Moroccans settle mostly in districts with between 10 and 100 percent non-western residents. In the terms of the Chicago School, there seems to 
be evidence here of succession: immigrants settling predominantly in districts where their compatriots are already represented to a reasonable extent.

$<$ Table 4 around here >

Next to that, we have also put into the frame whereabouts in the cities the immigrants from outside the Netherlands settled in 2002. The postcode area in which they settled immediately after their arrival is known for all the 32,165 immigrants arriving in one of the four big cities in 2002.

Table 4 shows big differences among people from different origin categories in the district in which they settle on arrival from abroad. Native Dutch arriving from abroad go mainly to districts with 5-25 percent non-western residents and to a lesser extent to districts with 25-50 percent non-western residents. Western origin immigrants strongly resemble the native Dutch in their behaviour. Almost 80 percent of all the Surinamese, Antilleans, Turks, and Moroccans arriving in the country settle in the four big cities in districts with 25-100 percent non-western residents. This finding is a strong indication that most immigrants go on arrival to districts where there are people of the same origin whom they already know (succession in terms of the Chicago School). A comparison of the neighbourhoods receiving immigrants from abroad with those receiving immigrants who come to the city from the rest of the Netherlands reveals some interesting differences. Native Dutch coming from the rest of the Netherlands to settle in one of the four big cities (table 4) settle in concentration neighbourhoods more often than do native Dutch immigrants. That probably comes about because among the inland migrants there are more young, starting households. For the non-western groups the pattern is the converse. The homeland migrants settle more frequently in the more white districts than do the migrants from abroad. This is an indication that there is a certain extent of spatial assimilation of immigrants the longer they remain in the Netherlands.

\section{Relocation flows within and between districts in the four big cities}

Table 5 shows for all those moving house in the four big cities and from the five most important categories of origin the percentage of non-western residents in the district from which they move and the percentage of non-western residents in the district to which they move. On the diagonal (in light grey) are the percentages of house moves within the same district, between districts in the same category in the same city or between two districts in the same category in two different cities (through-flow percentages). It can also be seen in the table what share of the movers leave the city (column 'to the rest of NL'). The extreme right column shows the percentage of the residents of the neighbourhood type and origin category concerned who moved house in 2002. To save space, in table 5 data for 'Other western immigrants' and 'Other non-western immigrants' have been omitted.

The table shows that native Dutch moving out of districts with 0-5 percent non-western immigrants for the most part move to districts with between 0 and 25 percent non-western immigrants. People moving out of concentration neighbourhoods (50-100 percent) are spread over districts with between 10 and 100 percent non-western immigrants. This 
pattern is very similar to the relocation pattern of western immigrants (not included in the table), but deviates markedly from the moving patterns of the other groups.

The other groups show a much larger outflow from districts with a low percentage of non-western residents to concentration neighbourhoods. Furthermore, the other groups show much less outflow out of concentration neighbourhoods and more through-flow. One fifth of all the native Dutch moving out of concentration neighbourhoods remained in the same type of district. The comparable figure for the Surinamese and Antilleans is almost two fifths and the shares are even larger for the Turks (54 percent) and Moroccans (47 percent). In the districts with 25-50 percent non-western residents, these groups also show a much higher percentage through-flow, with as much as 58 percent through-flow for Turks.

If we consider the movement of people from the origin categories out of the city (table 5: column 'to the rest of NL') we can observe some large differences. About 35 percent of all the native Dutch moving out of urban neighbourhoods go to the rest of the Netherlands. For people from all other origin categories this percentage of those moving away is much lower. It is striking that for Surinamese, Turks, and Moroccans the percentage of house movers who leave the city strongly decreases with the percentage of non-western residents in the neighbourhood. Apparently, the people in these groups who live in districts with a low percentage of non-western residents strongly resemble the native Dutch in their relocation behaviour, while those living in districts with a high percentage of non-western residents rarely succeed in leaving the city. It seems therefore that few immigrants make the step in one go from a concentration neighbourhood to a location outside the city. The urban neighbourhoods with a lower percentage of ethnic groups may well serve as an intermediate step towards the suburbs, which would conform with the spatial assimilation model (see also Burgess, 1925).

$<$ Table 5 around here $>$

\section{Relocation percentages according to land of origin and type of district}

Table 5 shows per origin category what percentage of the urban population in this group moved house in 2002. Of all the native Dutch, 11.9 percent relocated. In comparison, in the whole of the Netherlands every year about 10 percent of the population moves house. Turks and Moroccans show higher relocation percentages. In 2002, of all the Surinamese in the four big cities, 16.9 percent moved house, as did as many as 25.6 percent of the Antilleans. The differences between the groups can partly be explained by the differences in their age distribution. Bearing in mind that the Antillean group consists of many young people, it is logical that the percentage of immigrants relocating is high, because young people move more often than older people do. The poorer housing conditions of Antilleans could also contribute to the high residential mobility.

The last column of table 5 shows for each origin category per type of neighbourhood out of which people are moving the percentage of the group that has relocated. For the native Dutch, this percentage runs from 8.5 percent in districts with less than 5 percent of residents of non-western origin to 14.6 percent in districts where more than 50 percent of the residents are of non-western origin. This result seems to indicate a white flight of native residents from districts accommodating inhabitants of non-western 
origin. The percentage of house movers also increases for Surinamese and Antilleans as the percentage of non-western immigrants in their district increases. For Turks and Moroccans the converse is the case. The greater the increase in the percentage of nonwestern immigrants in the district, the smaller is the percentage of Turks and Moroccans who move out. This can indicate on the one hand that Turks and Moroccans feel more comfortable in immigrant districts, but also that they are less successful than other groups in leaving these districts.

In order to get more insight in the explanations for the differences in spatial behaviour between minority ethnic groups, it would be instructive to examine differences in socio-economic background and life cycle characteristics. The question is how much is left of the ethnic specificity in the moving behaviour of households if we control for these kind of background variables. To answer this question the next section presents an analysis based on two large scale surveys in the Netherlands: The Housing Demand Survey (HDS) 2002 and the Housing Research Netherlands (HRN) 2006 survey.

\section{Neigbourhood choice and ethnic specificity}

The HDS and HRN sample are large samples that are person-based and representative of the Dutch population aged 18 and over but not living in institutions. The data set contains not only information about the present housing situation but also about residential mobility since two years before the interview. For those who moved in the last two years, the previous housing situation and the previous postal code is known.

The data set contains geographical identifiers in the form of the postal code area. Four-digit postal code areas roughly correspond to the level of a neighbourhood. To make a distinction between concentration and non-concentration neighbourhoods, population data at the level of the postal code area, provided by Statistics Netherlands, are used.

We restricted our analyses to those who were heads of independent households and were living in one of four largest cities of the Netherlands.

When we break down the figures by ethnic group, the numbers of respondents in the Housing Demand Survey and 2002 and the Housing Research Netherlands (HRN) are fairly modest. Therefore, we have merged the four biggest ethnic minority groups to form two categories. Turks and Moroccans are combined to form one category. Secondly, Surinamese and Antilleans have been merged to form one category.

We consider a neighbourhood (in fact, the delimited areas are four-digit postal code areas) to be a concentration neighbourhood when the share of non-western minority-group residents is at least 40 per cent ${ }^{1}$, which is 10 per more than the average in the four big cities. In our analyses of the residential mobility between concentration neighbourhoods and other neighbourhoods, we have to distinguish between two groups: (1) those who have lived in a concentration neighbourhood two years before the interview or have moved out of a dwelling in such a neighbourhood since then; (2) those who have lived in a non-concentration neighbourhood or have moved out of a dwelling in such a

\footnotetext{
${ }^{1}$ Of course, the choice to define a concentration neighbourhood as an area where the share of minoritygroup residents is at least 40 per cent is somewhat arbitrarily. Therefore, we also used also two other dividing lines (35 per cent and 45 per cent) to distinguish between concentration neighbourhoods and other neighbourhoods. These different dividing lines did turn out not to yield noticeably different regression models than the ones that are presented in this paper.
} 
neighbourhood since then. Not surprisingly, the majority (around three-quarters) of the Native Dutch and Western immigrants falls into the latter category, while the majority of the other groups (ranging from 53 per cent of the other non-Western immigrants to 65 per cent of the Turks and Moroccans) fits into the former category.

Not only are the non-western categories strongly over-represented in concentration neighbourhoods, but they do not move away from those areas very often (Table 6). ${ }^{2}$ Only seven per cent of the Turks and Moroccans in the concentration neighbourhoods had moved into a non-concentration neighbourhood and that percentage is only slighter higher for Surinamese and Antilleans, and other non-Western immigrants. Next to that, Turks and Moroccans in non-concentration areas move relatively often to a concentration neighbourhood (almost 40 per cent of the Turkish and Moroccans movers), even compared to the other non-western categories. Consistent with the picture drawn in the previous section, the pattern for native Dutch and Western immigrants is completely different. The proportion in these categories that moved into a concentration neighbourhood is very small, especially for those who already lived in a non-concentration neighbourhood.

The question is to what extent the differences in neighbourhood choices can be explained by differences in background characteristics. To answer this question, we performed a multinomial logistic regression analysis for households in the concentration neighbourhoods (Table 7) as well as for households in the non-concentration neighbourhoods (Table 8). In both tables, the dependent variable consists of three categories: not moving; moving to a concentration neighbourhood; and moving to a nonconcentration neighbourhood. Of these categories, not moving is included as the reference category.

In each table we present two models. The first model includes only ethnicity as independent variable and. Model 2 is a full model in which the effect of ethnicity is controlled for all relevant variables that are available in the dataset, i.e. life cycle characteristics (age and household composition), socio-economic characteristics (income and level of education) and tenure. Next to that, we control for a period and a geographical variable. As the average proportion of non-western minorities in the neighbourhood has risen in the course of the four years between HDS 2002 and HNR 2006 (from 28.9 tot 32.5 per cent), we included a dummy to distinguish between these two surveys. Furthermore, we added a dummy to distinguish between Utrecht and Amsterdam at the one hand and The Hague and Rotterdam at the other hand, as the housing market of the former cities is much tighter than the housing market of the latter cities.

For the purpose of this article it is mainly important to look what happens with the effects of ethnicity when the other variables are controlled for. Looking at the analysis on the residential mobility out of concentration neighbourhoods, it can be concluded that the non-western categories are much less likely to move into a non-concentration neighbourhood than the Western immigrants and the native Dutch, even when differences

\footnotetext{
${ }^{2}$ The percentages in Table 3 are weighted percentages. The reason is that about 12 per cent of the respondents who had moved in the previous two years could not recall their previous postal code. In those instances, we could not determine whether they had come from a concentration neighbourhood or a nonconcentration neighbourhood. In order to compensate for the under-representation of those who had moved away, we gave extra weight in the analyses to the answers of those who did remember the postal code of their previous dwelling.
} 
in the control variables are taken into account. And also with respect to the moves out of non-concentration neighbourhoods (Table 8), the picture does not change in essence when we take background variables into account. Only for Turks and Moroccans and other nonWestern immigrants we can conclude that their inclination to move to concentration neighbourhoods can to a limited extent be attributed to their background characteristics. ${ }^{3}$

We may conclude that there is an ethnic specificity in the moving behaviour of households. Even when we take all kinds of individual variables into account, minority groups still end up much more often in a concentration neighbourhood when they move than the indigenous groups do. One of the possible explanations for this ethnic specificity is that there are differences in neighbourhood preferences between the ethnic groups. It might be that native Dutch do prefer to live in neighbourhood where they form the large majority and therefore try to avoid concentration neighbourhoods. On the basis of the HDS/HNR surveys several indications can be found that would support this explanation.

Respondents in the survey were asked whether they agreed or not with several statements on their neighbourhood. For every ethnic category, there is a negative association between the proportion non-western minorities in the neighbourhood and the satisfaction with the population composition. This association is strongest for the native Dutch and weakest for Turks and Moroccans. Except for Turks/Moroccans and Surinamese/Antilleans, there is also a negative relation between living in a concentration neighbourhood and social ties with people in the neighbourhood. For non of the groups a positive association is found, although the availability of social ties within the own ethnic group is often seen as an advantage of concentration neighbourhood (Bolt et al., 1998). Of course, we might have found a relation is we would have had information on the percentage of ones own ethnic group in the neighbourhood.

On the basis of table 9 it can also be concluded that the ethnic composition of the neighbourhood has an influence on the moving wishes of households. For every category, a higher proportion of ethnic minorities in the neighbourhood increases the chance that one wants to leave the neighbourhood. Again, this association is substantially stronger for the native Dutch and the Western immigrants than for the other groups. This difference also holds when differences in background variables are controlled for (Van Ham and Feijten, 2007). This support the idea that ethnic differences in neighbourhood choices are at least partly explained by differences in neighbourhood preferences.

\section{Conclusions}

Although the level of ethnic segregation in the biggest Dutch cities is fairly stable or even declining (in the case of Rotterdam), there is an increasing concern among politicians about the (supposedly) detrimental effects of segregation on the integration of minority ethnic groups. Undoubtedly, this concern is partly brought about by the increasing share of ethnic groups in the cities. As a consequence, the average member of a minority ethnic group now lives in a district with a lower share of native Dutch than a few years ago, despite the fact that the level of ethnic segregation did not increase.

\footnotetext{
${ }^{3}$ This is concluded on the basis of the differences between the two regression coefficients. For Turks and Moroccans and other non-Western immigrants, this difference is somewhat smaller in model 2 than in model 1(table 8).
} 
To combat the negative effects of socio-economic and ethnic concentration, The Dutch government has implemented an ambitious social mixing policy, mainly leaning on urban renewal. This urban renewal policy is based on a number of assumptions which are questionable:

1) The residential concentration of minority ethnic groups hampers their integration into Dutch society.

2) Mixing of ethnic groups leads to social interaction between different groups. Moreover, people with a higher social status may act as positive role models for the other residents.

3) Ethnic segregation is the result of socio-economic segregation and socioeconomic segregation is the consequence of the spatial distribution of affordable housing.

The first assumption disregards the possibility that concentrations may have a positive effect. Even proponents of the spatial assimilation model see ethnic concentration as a haven for integration and adaptation (Dunn, 1998). Next to that, little research has been done in the Netherlands into the effects of ethnic concentration. In one study, it is found that living in concentration neighbourhoods has a negative effect on the number of contacts with native Dutch (Gijsberts and Dagevos, 2005), but is not clear how this relates to social mobility or acculturation.

With regard to the second assumption, existing studies on mixed developments do not justify the optimism concerning the social interaction between (ethnic) groups, let alone the possibilities for social mobility that should arise from that. Next to that, the idea that people with a higher social status might act as positive role models is patronising and based on unfounded assumptions with regard to differences in values between ethnic and socio-economic categories.

Finally, the idea that differentiation is an effective means to combat segregation disregards the fact that spatial segregation is determined by a large number of factors, many of which are unrelated to the housing stock characteristics of neighbourhoods (Musterd, 2003; Van Kempen and Özüekren, 1998). In this paper, we have specifically looked at ethnic-specific differences with regard to neighbourhood choice. We have found that native Dutch and Western immigrants are much more likely than non-western groups to move out of concentration neighbourhood and to opt more often for neighbourhoods with a low proportion of minorities. The other groups succeed in leaving the concentration neighbourhoods to a much lesser extent. There is less outflow and much more throughflow within concentration neighbourhoods. The inflow into concentration neighbourhoods from the rest of Netherlands and from abroad is greater. This inflow strengthens the segregation in cities and conforms with the findings of Latten and colleagues (2005) that the concentration of immigrants in Netherlands is increasing. The Turks and Moroccans in the four big cities are noteworthy on two important points. First, there is much more through-flow within concentration neighbourhoods. Second, the percentage of the house movers who leave the city is lower, as the percentage of non-western residents in the district is higher. This seems to suggest that Turks and Moroccans are particularly unsuccessful in moving out of concentration neighbourhoods.

The ethnic differences in neighbourhood choices can only to a very limited extent be attributed to differences in socio-economic status. The reluctance of many native Dutch to live in a neighbourhood with a substantial proportion of members of minorities ethnic 
groups forms a major obstacle for urban policy aiming at countering segregation. While the policy discourse focuses on the need to combat the concentration of minority ethnic groups, there are hardly possibilities to deal with one of its main causes, i.e. the selfsegregation tendencies among the native majority.

An important challenge for researchers is to search more deeply for the reasons for these ethnic differences in neighbourhood choices (Emerson et al., 2001; Harris, 2001). Do native Dutch avoid concentration neighbourhoods because they are averse to living amongst minority ethnic groups (consistent with the pure 'race' hypothesis) or is it that the presence of a (substantial number of) members of minority ethnic groups stands for other characteristics of the neighbourhood (consistent with the 'racial' proxy hypothesis). Future quantitative research on neighbourhood choice should take into account relevant neighbourhood amenities that are associated with the ethnic composition of the neighbourhood, while qualitative research may shed more light into the motivations that underlie the neighbourhood choice of households.

\section{Literature}

AALBERS, M.B. (2005) Who's afraid of red, yellow and green? Redlining in Rotterdam, Geoforum, 36, pp. 562-580.

AELBERS, O., SMEETS, J. and VAN DER VEN, H. (1991) Op hun plaats? Allochtonen en moeilijk verhuurbare woningcomplexen. Den Haag: Ministerie van VROM.

ANDERSON, E. (1999) Code of the street: Decency, violence, and the moral life of the inner city. New York: W.W. Norton.

ANDERSSSON, R. (2006) 'Breaking segregation'-Rhetorical construct or effective policy? Urban Studies, 43, pp. 787-799.

ATKINSON, R. and KINTREA, K. (2000) Owner-occupation, social mix and neighbourhood impacts. Policy \& Politics, 28, pp. 93-108.

BOAL, F. W. (1976) Ethnic residential segregation. In D. T. Herbert \& R. J. Johnston (Eds.), Social areas in cities (pp. 41-79). London: John Wiley \& Sons.

BOLT, G. (2001) Wooncarrières van Turken en Marokkanen in ruimtelijk perspectief. Utrecht: Faculteit Ruimtelijke Wetenschappen.

BOLT, G. (2004). Over spreidingsbeleid en drijfzand. Migrantenstudies, 20, pp. 60-73.

BOLT, G., BURGERS, J., and VAN KEMPEN, R. (1998). On the social significance of spatial location; spatial segregation and social inclusion. Netherlands Journal of Housing and the Built Environment, 13, pp. 83-95.

BOLT, G., HOOIMEIJER, P. and VAN KEMPEN, R. (2002) Ethnic segregation in the Netherlands: new patterns, new policies? Tijdschrift voor Economische en Sociale Geografie, 93, pp. 214-220.

BOLT, G. and VAN KEMPEN, R. (2000) Concentratie en segregatie in Nederlandse steden. In R. van Kempen, P. Hooimeijer, G. Bolt, J. Burgers, S. Musterd, W. Ostendorf and E. Snel (Eds.), Segregatie en concentratie in Nederlandse steden: mogelijke effecten en mogelijk beleid (pp. 13-34). Assen: Van Gorcum

BOLT, G. and VAN KEMPEN, R. (2002) Wonen in multiculturele steden. Den Haag: Ministerie van VROM.

BOWES, A.M., DAR, N.S. and SIM, D.F. (2002). Differentiation in housing careers: the case of Pakistanis in the UK. Housing Studies, 17, pp. 381-399. 
BRAMLEY, G. and MORGAN, J. (2003). Building competitiveness and cohesion: the role of new housebuilding in central Scotland's cities. Housing Studies, 18, pp. 447-471.

BROPHY, P.C. and SMITH, R.N. (1997). Mixed-income housing: factors for success. Cityscape, 3, pp. 3-31.

BUCK, N. (2001) Identifying neighbourhood effects on social exclusion. Urban Studies, 38 , pp. 2251-2275.

BURGERS, J. and VAN DER LUGT, H. (2005) 'Zwarte vlucht' The suburbanisatie van Surinamers uit Rotterdam. Sociologie, 1, 126-142.

BURGESS, E. W. (1925) The growth of the city: an introduction to a research project. In R.E. Park, E.W. Burgess and R.D. McKenzie The city, pp. 47-62. Chicago: The University of Chicago Press.

CHARLES, C.Z. (2003) Dynamics of residential segregation. Annual Review of Sociology, 29, 167-207.

CLARK, W.A.V. (1991) Residential Preferences and Neighborhood Racial Segregation: A Test of the Schelling Segregation Model. Demography, 28, pp. 1-19.

CRANE, J. (1991) The epidemic theory of ghettos and neighborhoods effects on dropping out and teenage childbearing. American Journal of Sociology, 96, pp. 1226-1259.

CRUMP, J. (2002). Deconcentration by demolition: public housing, poverty, and urban policy. Environment and Planning D: Society and Space, 20, pp. 581-596.

DE GROOT, C. (2004) 'Zwarte vlucht' - De sub(urbane) locatiekeuze van klassieke allochtonen in Amsterdam. Den Haag: Ministerie van VROM.

DEKKER, K. and BOLT, G. (2005). Social cohesion in post-war estates in the Netherlands: Differences between socioeconomic and ethnic groups. Urban Studies, 42, pp. 2447-2770.

DUNCAN, G., BROOKS-GUNN, J. and KLEBANOV, P. (1994) Economic deprivation and early childhood development. Child Development, 65, pp. 296-318.

DUNN, K.M. (1998). Rethinking ethnic concentration: The case of Cabramatta, Sydney. Urban Studies, 35, pp. 503-524.

EMERSON, M. O., YANCEY, G., and CHAI, K. J. (2001). Does race matter in residential segregation? Exploring the preferences of white Americans. American Sociological Review, 66, pp. 922-935.

FRIEDRICHS, J. and BLASIUS, J. (2003) Social norms in distressed neighbourhoods: Testing the Wilson hypothesis. Housing Studies, 18, pp. 807-826.

GALSTER, G.C. (1999) The evolving challenges of fair housing since 1968: Open housing, integration, and the reduction of ghettoization. Cityscape: A Journal of Policy Development and Research, 4, pp. 123-138.

GALSTER, G. (2005) Neighbourhood mix, social opportunities, and the policy challenges of an increasingly diverse Amsterdam. Wibaut lecture. Amsterdam: AMIDSt.

GALSTER, G.C., METZGER, K. and WAITE, R. (1999) Neighborhood opportunity structures and immigrants' socioeconomic advancement. Journal of Housing Research, 10, pp. 95-127.

GANS, H.J. (1961). The balanced community - Homogeneity or heterogeneity in residential areas? Journal of the American Institute of Planners, 27, pp. 176-184.

GIFFINGER, R. (1998) Segregation in Vienna: impacts of market barriers and rent regulations. Urban Studies, 35, pp. 1791-1812. 
GIJSBERTS, M. and DAGEVOS, J. (2005) Uit elkaars buurt. De invloed van etnische concentratie op integratie en beeldvorming. Den Haag: Sociaal en Cultureel Planbureau.

GLEBE, G. (1997) Urban economic restructuring and ethnic segregation in Düsseldorf. Tijdschrift voor Economische en Sociale Geografie, 8, pp. 147-157.

GORDON, M.M. (1964) Assimilation in American Life. New York: Oxford University Press.

HARRIS, D.R. (2001) Why are whites and blacks averse to black neighbors? Social Science Research, 30, pp. 100-116.

ILHANFELDT, K.R. and SCAFIDI, B. (2004). Whites' neighbourhood racial preferences and neighbourhood racial composition in the United States: Evidence from the multi-city study of urban inequality. Housing Studies, 19, pp. 325-359.

IHLANFELDT, K.R. and SJOQUIST, D.L. (1998) The spatial mismatch hypothesis: A review of recent studies and their publications for welfare reform. Housing Policy Debate, 9, pp. 849-892.

JOSEPH, M.L., CHASKIN, R.J. and WEBBER, H.S. (2007). The theoretical basis for addessing poverty through mixed-income development. Urban Affairs Review, 42, pp. 369-409.

KEMPEN, R. VAN (2005) Segregation and housing conditions of immigrants in Western European cities, in: Y. Kazepov (Ed.) Cities of Europe: Changing Contexts, Local Arrangements, and the Challenge to Urban Cohesion (pp.190-209). Oxford: Blackwell.

KLEINHANS, R. (2004) Social implications of housing diversification in urban renewal: A review of recent literature. Journal of Housing and the Built Environment, 19, pp. 367-390.

LATTEN, J., NICOLAAS, H. and WITTEBROOD, K. (2005) Concentratie allochtonen toegenomen. In Bevolkingstrends. Jaargang 53 - 3e kwartaal 2005, pp. 90-95. Heerlen/Voorburg: Centraal Bureau voor de Statistiek.

LIEBERSON, S. (1961) The impact of residential segregation on ethnic assimilation. Social Forces, 40, pp. 52-57.

LOGAN, J.R. and ALBA, R.D. (1993) Locational returns to human capital: Minority access to suburban community resources. Demography, 30, pp. 243-267.

MASSEY, D.S. (1985) Ethnic residential segregation: A theoretical synthesis and empirical review. Sociology and Social Research, 69, pp. 315-350.

MASSEY, D.S. and DENTON, N.A. (1988) The dimensions of residential segregation. Social Forces, 67, pp. 281-315.

MASSEY, D.S. and DENTON, N.A. (1993) American apartheid: Segregation and the making of the underclass. Cambridge: Harvard University Press.

MASSEY, D.S. and FONG, E. (1990) Segregation and neighborhood quality: Blacks, Hispanics, and Asians in the San Fransisco metropolitan area. Social Forces, 69, pp.15-32.

MINISTERIE VAN JUSTITIE (2004) Kabinetsreactie op het rapport "Bruggen Bouwen" van de tijdelijke commissie onderzoek integratiebeleid. '-Gravenhage: SDU.

MINISTERIE VAN JUSTITIE (2005) Jaarnota integratiebeleid 2005. Den Haag: Ministerie van Justitie.

MINISTERIE VROM (1997) Nota Stedelijke Vernieuwing. Den Haag: Ministerie van Volkshuisvesting, Ruimtelijke Ordening en Milieubeheer 
MUSTERD, S. (2003) Segregation and integration: a contested relationship. Journal of Ethnic and Migration Studies, 29, pp. 623-641.

MUSTERD, S. (2005) Social and ethnic segregation in Europe: levels, causes, and effects. Journal of Urban Affairs, 27, pp. 331-348.

MUSTERD, S., OSTENDORF, W. and BREEBAART, M. (1998) Multi-ethnic Metropolis: Patterns and Policies. Dordrecht: Kluwer Academic Publishers.

MUSTERD, S., OSTENDORF, W. and DE VOS, S. (2003) Neighbourhood effects and social mobility: a longitudinal analysis. Housing Studies, 18, pp. 877-892.

MUSTERD, S., PRIEMUS, H. and VAN KEMPEN, R. (1999) Towards undivided cities: the potential of economic revitalisation and housing redifferentiation. In: Housing Studies 14, pp. 573-584.

OVERMAN, H.G. (2002) Neighbourhood effects in large and small neighbourhoods. Urban Studies, 39, pp. 117-130.

ÖZÜEKREN, A.S. and VAN KEMPEN, R. (2003) Dynamics and diversity: housing careers and segregation of minority ethnic groups. Housing, theory and society, 20, pp. 162-171.

PARK, R.E. (1925) The city: suggestions for the investigation of human behavior in the urban environment. R.E. Park, E.W. Burgess and R.D. McKenzie R.E. The City, pp. 1-46. Chicago: University of Chicago Press.

PHILLIPS, D. (1998) Black minority ethnic concentration and dispersal in Britain. Urban Studies, 35, pp. 1681-1702.

PHILLIPS, D. and KARN, V. (1992) Race and housing in a property owning democracy. New Community, 18, pp. 355-369.

PORTES, A., \& ZHOU, M. (1993). The new second generation: Segmented assimilation and its variants. The Annals of the American Academy of Political and Social Science, 530, pp. 74-96.

ROBINSON, V. (1981) The development of South Asian settlement in Britain and the myth of return. In C. Peach, V. Robinson and S. Smith (Ed.) Ethnic Segregation in Cities, pp. 149-169. London: Croom Helm.

ROSENBAUM, J.E., STROH, L.K. and FLYNN, C.A. (1998). Lake Parc Place: a study of mixed-income housing. Housing Policy Debate, 9, pp. 703-740.

SAMPSON, R., RAUDENBUSH, S. and EARLS, F., (1997) Neighbourhoods and violent crime: A multilevel study of collective efficacy. Science, 277, pp. 918-924.

SCHELLING, T.C. (1969) Models of segregation. The American Economic Review, 59, pp. 488-493.

SCP/WODC/CBS (2005) Jaarrapport integratie 2005. Den Haag: SCP/WODC/CBS.

SOUTH, S.J. and CROWDER, K.D. (1998) Leaving the 'hood': Residential mobility between black, white and integrated neighborhoods. American Sociological Review, 63, pp. 17-26.

SOUTH, S.J., CROWDER, K. and CHAVEZ, E. (2005) Migration and spatial assimilation among U.S. Latinos: classical versus segmented trajectories. Demography, 42, pp. 497-521.

UITERMARK, J. (2003). 'Social mixing' and the management of disadvantaged neighbourhoods: The Dutch policy of urban restructuring revisited. Urban Studies, 40, pp. 531-549. 
UUNK, W. (2002) Concentratie en achterstand - over de samenhang tussen etnische concentratie en de sociaal-economische positie onder allochtonen en autochtonen. Assen: Van Gorcum.

UUNK, W. and DOMINGUEZ MARTINEZ, S. (2002) Wijken in beweging: Migratie in en uit concentratiewijken. Assen: Koninklijke Van Gorcum.

VAN AMERSFOORT, H. (1992) Ethnic residential patterns in a welfare state: Lessons from Amsterdam. New Community, 18, pp. 439-456.

VAN BECKHOVEN, E. and VAN KEMPEN, R. (2003) Social effects of urban restructuring: a case study in Amsterdam and Utrecht, the Netherlands, Housing Studies , 18, pp. 853-875.

VAN DER KLAAUW, B. and VAN OURS, J.C. (2003) From welfare to work: does the neighborhood matter? Journal of Public Economics, 87, 957-985.

VAN HAM, M. and FEIJTEN, P. (2007) Who wants to leave the neighbourhood? The effect on moving wishes of being different from the neighbourhood population. Environment and Planning A, 39 (forthcoming)

VAN HUIS, L.T. and NICOLAAS, J.M.M. (2000) Allochtonen en hun verhuisgedrag, Allochtonen in Nederland 2000 (pp. 15-19). Voorburg: CBS.

VAN KEMPEN. R. and BOLT, G. (2002) Is falend grotestedenbeleid oorzaak LPF-winst? Geografie, 11, pp. 21-25.

VAN KEMPEN. R. and ÖZÜEKREN A.S. (1998) Ethnic segregation in cities: new forms and explanations in a dynamic world. Urban Studies, 35, pp. 1631-1656.

VAN KEMPEN, R. and PRIEMUS, H. (1999) Undivided cities in the Netherlands: present situation and political rhetoric. Housing Studies, 14, pp. 641-657.

VAN KEMPEN, R. and PRIEMUS, H. (2002) Revolution in social housing in the Netherlands: possible effects of new housing policies. Urban Studies, 39, pp. 237 253.

VELDBOER, L., KLEINHANS, R. and DUYVENDAK, J. W. (2002) The diversified neighbourhood in Western Europe and the United States: How do countries deal with the spatial distribution of economic and cultural differences? Journal of International Migration and Integration, 3, pp. 41-64.

WHITE, M. J. (1983) The measurement of spatial segregation. American Journal of Sociology, 88, pp. 1008-1019.

WILKES, R. and ICELAND, J. (2004) Hypersegregation in the twenty-first century. Demography, 41, pp. 23-36.

WILSON, W.J. (1987) The truly disadvantaged: the inner city, the underclass and public policy. Chicago: the University of Chicago Press.

YINGER, J. (1999) Sustaining the fair housing act. Cityscape: A Journal of Policy Development and Research, 4, pp. 93-106. 
Table 1: Ethnic minorities in the of the four big cities (Amsterdam, Rotterdam, Utrecht, The Hague) as percentage of the national total (in 2004); immigrants in the four big cities as percentage of the national inflow of immigrants (in 2002).

\begin{tabular}{llc}
\hline & $\begin{array}{c}\text { \% living in } 4 \text { big cities per } \\
\text { ethnic group (2004) }\end{array}$ & $\begin{array}{l}\text { \% immigrants settling down } \\
\text { in 4 big cities (2002) }\end{array}$ \\
\hline Turks & 35,5 & 36,9 \\
Moroccans & 47,3 & 49,0 \\
Surinamese & 53,8 & 57,4 \\
Antillians & 34,2 & 40,2 \\
Other non-western immigrants & 30,7 & 21,7 \\
Westerne immigrants & $17,1^{\mathrm{a}}$ & 27,3 \\
Native Dutch & $9,0^{\mathrm{a}}$ & 13,3 \\
Total Dutch population & 12,8 & 26,5 \\
\hline
\end{tabular}

${ }^{\mathrm{a}}$ Data 2002

Source: SCP/WODC/CBS 2005; CBS Statline: own processing

Table 2: $\quad$ Segregation-index of minority ethnic groups in the four big cities

\begin{tabular}{|c|c|c|c|c|c|}
\hline & Turks & Moroccans & Surinamese & Antilleans & $\begin{array}{l}\text { Non-western } \\
\text { minotities }\end{array}$ \\
\hline \multicolumn{6}{|c|}{ Amsterdam } \\
\hline 1980 & 37,3 & 38,6 & 27,8 & 26,2 & \\
\hline 1986 & 38,8 & 36,9 & 33,7 & 33,0 & \\
\hline 1995 & 40,7 & 39,1 & 34,8 & 34,9 & \\
\hline 2000 & 41,2 & 39,5 & 33,3 & 37,1 & 34,9 \\
\hline 2004 & 42,4 & 40,0 & 32,9 & 33,3 & 36,3 \\
\hline \multicolumn{6}{|c|}{ Rotterdam } \\
\hline 1995 & 51,7 & 46,8 & 28,6 & 28,5 & \\
\hline 2000 & 47,8 & 42,6 & 24,1 & 30,2 & 40,8 \\
\hline 2004 & 44,1 & 39,7 & 21,1 & 29,7 & 38,5 \\
\hline \multicolumn{6}{|c|}{ The Hague } \\
\hline 1980 & 66,4 & 64,7 & & & \\
\hline 1986 & 65,1 & 57,3 & 46,4 & 26,9 & \\
\hline 1995 & 54,6 & 49,9 & 40,2 & 25,5 & \\
\hline 2000 & 51,3 & 48,6 & 37,0 & 27,3 & 45,7 \\
\hline 2004 & 51,1 & 48,3 & 33,5 & 28,1 & 46,1 \\
\hline \multicolumn{6}{|c|}{ Utrecht } \\
\hline 1995 & 43,2 & 42,2 & 24,0 & 22,5 & \\
\hline 2000 & 38,8 & 39,4 & 20,3 & 16,7 & 34,8 \\
\hline 2004 & 42,3 & 43,6 & 22,4 & 16,4 & 37,4 \\
\hline \multicolumn{6}{|c|}{ Municipalities > 100.000 inhabitants } \\
\hline 2003 & 39 & 38 & 23 & 24 & \\
\hline \multicolumn{6}{|c|}{ Municipalities 50.000-100.000 inhabitants } \\
\hline 2003 & 35 & 36 & 20 & 23 & \\
\hline
\end{tabular}

Source: Bestuursinformatie Gemeente Utrecht; Bolt and Van Kempen (2000); COS Rotterdam; Gemeente Den Haag; Van der Laan Bouma-Doff, 2005a; O+S Amsterdam; SCP/WODC/CBS, 2005 . 
Table 3: Population of the four big cities (Amsterdam, Rotterdam, Utrecht, The Hague) by ethnicity and neighbourhood type

\begin{tabular}{lrrrrrr}
\hline & \multicolumn{6}{c}{ Percentage non-western ethnic minorities in the neighbourhood } \\
& $0-5 \%$ & $5-10 \%$ & $10-25 \%$ & $25-50 \%$ & $50-100 \%$ & Total \\
\hline Native Dutch & 4.4 & 19.1 & 36.7 & 32.5 & 7.4 & $1,186,703$ \\
Surinamese & 0.4 & 3.3 & 19.2 & 42.6 & 34.6 & 173,710 \\
Antillians & 0.7 & 5.1 & 20.8 & 40.1 & 33.3 & 42,893 \\
Turks & 0.2 & 1.4 & 11.3 & 44.2 & 42.9 & 117,663 \\
Moroccans & 0.2 & 1.7 & 13.9 & 51.1 & 33.2 & 135,004 \\
Western imm. & 2.6 & 20.9 & 33.2 & 32.9 & 10.3 & 240,704 \\
Other non- & & & & & & \\
western imm. & 0.7 & 6.6 & 20.4 & 40.7 & 31.7 & 155,210 \\
Total & 3.0 & 14.5 & 30.3 & 36.1 & 16.2 & $2,051,887$ \\
\hline
\end{tabular}

Source: GBA data 2002, CBS (Centraal Bureau voor de Statistiek); own processing

Table 4: Inflow of migrants into the four big cities from the rest of the Netherlands and from abroad by ethnicity and neighbourhood type

\begin{tabular}{|c|c|c|c|c|c|c|}
\hline \multicolumn{7}{|c|}{ Inflow from the rest of the Netherlands } \\
\hline & \multicolumn{5}{|c|}{$\begin{array}{l}\text { Neighbourhoods of destination, } \% \text { non-western } \\
\text { minorities: }\end{array}$} & \multirow{2}{*}{$\begin{array}{l}\text { Absolute } \\
\text { numbers } \\
(100 \%)\end{array}$} \\
\hline & $0-5 \%$ & $5-10 \%$ & $10-25 \%$ & $25-50 \%$ & $50-100 \%$ & \\
\hline Native Dutch & 3.4 & 18.7 & 41.9 & 27.5 & 8.5 & 45302 \\
\hline Surinamese & 0.9 & 4.7 & 28.4 & 37.6 & 28.4 & 4233 \\
\hline Antillians & 0.6 & 7.5 & 22.3 & 37.2 & 32.4 & 2476 \\
\hline Turks & 1.5 & 4.0 & 23.1 & 37.1 & 34.3 & 1717 \\
\hline Moroccans & 0.8 & 6.3 & 21.6 & 44.8 & 26.4 & 1869 \\
\hline Western imm. & 2.1 & 18.2 & 38.0 & 30.6 & 11.2 & 8353 \\
\hline $\begin{array}{l}\text { Other non-western } \\
\text { imm. }\end{array}$ & 0.7 & 8.4 & 27.0 & 38.11 & 258 & 8421 \\
\hline Total & 2.6 & 15.6 & 37.3 & 30.7 & 13.9 & 72371 \\
\hline \multicolumn{7}{|l|}{ Inflow from abroad } \\
\hline & \multicolumn{5}{|c|}{$\begin{array}{l}\text { Neighbourhoods of destination, \% non-western } \\
\text { minorities: }\end{array}$} & $\begin{array}{r}\text { Absolute } \\
\text { numbers } \\
(100 \%)\end{array}$ \\
\hline Native Dutch & 3.3 & 31.5 & 35.5 & 23.0 & 6.6 & 2410 \\
\hline Surinamese & 0.5 & 3.3 & 13.9 & 41.8 & 40.6 & 2130 \\
\hline Antillians & 0.8 & 4.8 & 18.2 & 39.2 & 37.0 & 2500 \\
\hline Turks & 0.0 & 2.0 & 11.3 & 46.8 & 39.9 & 2445 \\
\hline Moroccans & 0.3 & 2.4 & 13.2 & 52.8 & 31.3 & 2700 \\
\hline Western imm. & 2.8 & 29.5 & 30.9 & 25.8 & 11.1 & 11425 \\
\hline Other non-western & & & & & & \\
\hline imm. & 1.0 & 12.6 & 26.1 & 33.3 & 27.0 & 8555 \\
\hline Total & 1.6 & 17.1 & 24.8 & 33.6 & 22.9 & 32165 \\
\hline
\end{tabular}

Source: GBA data 2002. CBS (Centraal Bureau voor de Statistiek); own processing 
Table 5: Relocation to, from, and between neighbourhoods with different concentrations of non-western immigrants by ethnicity of the movers (outflow percentages) for the four big cities

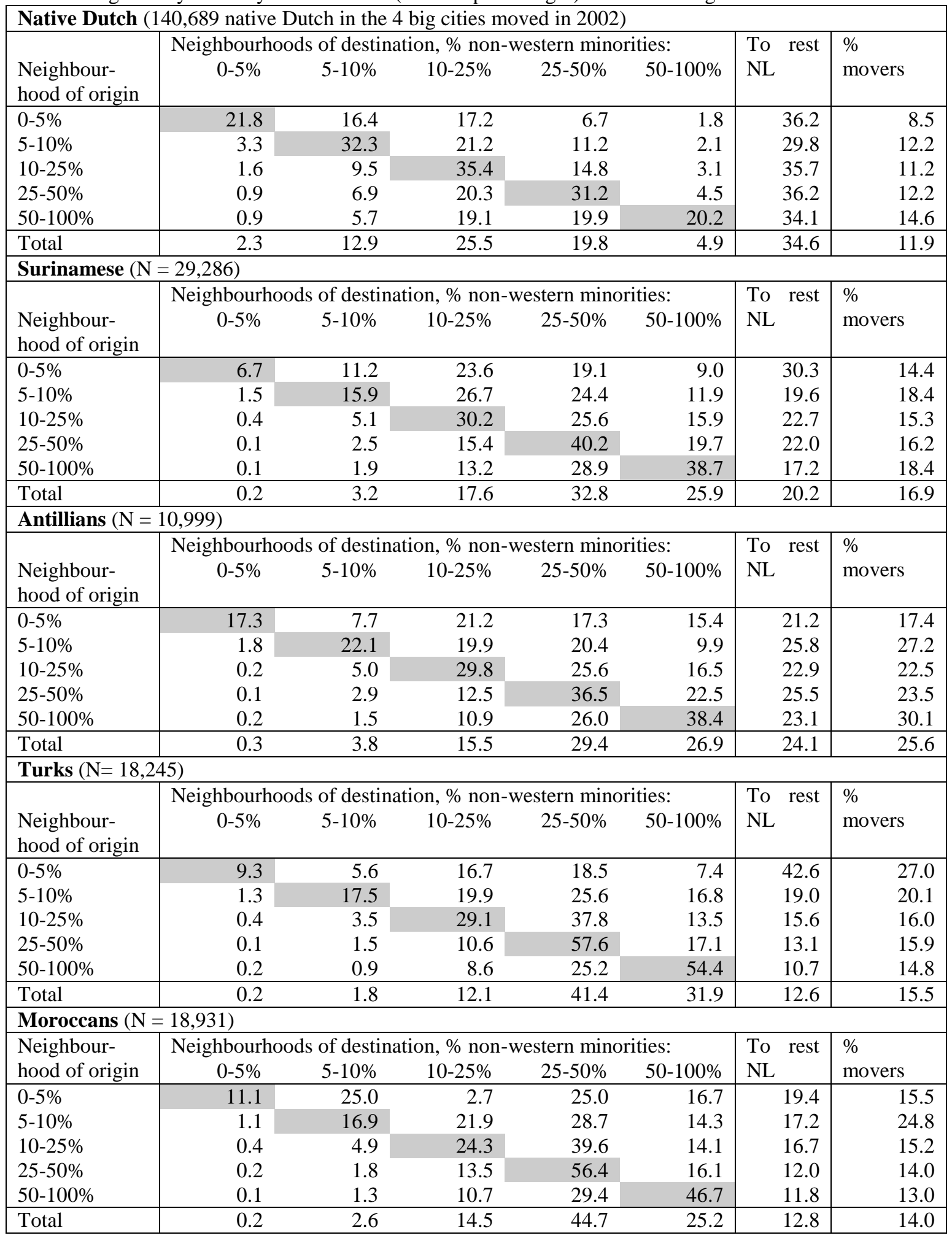

Source: GBA data 2002. CBS (Centraal Bureau voor de Statistiek); own processing 
Table 6: $\quad$ Residential mobility pattern of households by ethnicity and type of neighbourhood (two years before the interview, percentages)

\begin{tabular}{|c|c|c|c|c|c|}
\hline & $\begin{array}{l}\text { Native } \\
\text { Dutch }\end{array}$ & $\begin{array}{r}\text { Surinamese } \\
\text { and } \\
\text { Antilleans } \\
\end{array}$ & $\begin{array}{r}\text { Turks and } \\
\text { Moroccans }\end{array}$ & $\begin{array}{r}\text { Other non- } \\
\text { western } \\
\text { imm. }\end{array}$ & $\begin{array}{r}\text { Western } \\
\text { immigrants }\end{array}$ \\
\hline \multicolumn{6}{|c|}{ Concentration neighbourhoods } \\
\hline Did not move & 77.7 & 78.0 & 82.1 & 77.3 & 73.4 \\
\hline $\begin{array}{l}\text { Moved to a concentration } \\
\text { neighbourhood }\end{array}$ & 6.4 & 13.1 & 10.8 & 13.8 & 7.8 \\
\hline $\begin{array}{l}\text { Moved to a non- } \\
\text { concentration } \\
\text { neighbourhood }\end{array}$ & 15.8 & 9.0 & 7.1 & 8.9 & 18.8 \\
\hline Number & 2083 & 781 & 694 & 449 & 399 \\
\hline \multicolumn{6}{|c|}{ Non- concentration neighbourhoods } \\
\hline Did not move & 77.9 & 75.9 & 76.3 & 71.8 & 76.6 \\
\hline $\begin{array}{l}\text { Moved to a non- } \\
\text { concentration neighbourhood }\end{array}$ & 20.4 & 17.8 & 14.5 & 21.9 & 20.5 \\
\hline $\begin{array}{l}\text { Moved to a } \\
\text { concentration neighbourhood }\end{array}$ & 1.7 & 6.3 & 9.2 & 6.3 & 2.9 \\
\hline Number (unweighted) & 6930 & 602 & 393 & 411 & 1060 \\
\hline
\end{tabular}

Source: Housing Demand Survey 2002, CBS/VROM; Housing Research Netherlands 2006, VROM 
Table 7: $\quad$ Multinomial logistic regression analysis of residential mobility out of concentration neighbourhoods

\begin{tabular}{|c|c|c|c|c|}
\hline & \multicolumn{2}{|l|}{ Model 1} & \multicolumn{2}{|l|}{ Model 2} \\
\hline & $\begin{array}{l}\text { Moved to a concentration } \\
\text { neighbourhood } \\
\text { B }\end{array}$ & $\begin{array}{l}\text { Moved to a non- } \\
\text { concentration } \\
\text { neighbourhood } \\
\quad \text { B }\end{array}$ & $\begin{array}{l}\text { Moved to a concentration } \\
\text { neighbourhood } \\
\text { B }\end{array}$ & $\begin{array}{l}\text { Moved to a non- } \\
\text { concentration } \\
\text { neighbourhood } \\
\quad \text { B }\end{array}$ \\
\hline \multicolumn{5}{|l|}{ Group (ref=native Dutch) } \\
\hline Turks/Moroccans & $0.469 * * *$ & $-0.868 * * *$ & 0.015 & $-1.208 * * *$ \\
\hline Surinamese/Antilleans & $0.710 * * *$ & $-0.573 * * *$ & $0.539 * * *$ & $-0.615 * * *$ \\
\hline Other non-western immigrants & $0.772 * * *$ & $-0.563 * * *$ & $0.417 * *$ & $-0.765 * * *$ \\
\hline Western immigrants & $0.237 * * *$ & 0.221 & 0.112 & 0.068 \\
\hline \multicolumn{5}{|c|}{$\begin{array}{l}\text { Urban housing market (ref= Rotterdam/The } \\
\text { Hague) }\end{array}$} \\
\hline Amsterdam/Utrecht & & & -0.034 & -0.063 \\
\hline Age & & & $-0.167 * * *$ & $-0.140 * * *$ \\
\hline Age squared $\left(* 10^{3}\right)$ & & & $1.246 * * *$ & $0.933 * * *$ \\
\hline \multicolumn{5}{|c|}{ Household composition (ref=single) } \\
\hline Couple & & & -0.044 & $0.463 * * *$ \\
\hline Couple with children & & & -0.176 & $-0.334 * *$ \\
\hline One parent-household & & & -0.169 & -0.296 \\
\hline Other & & & 0.245 & 0.117 \\
\hline Annual income (z-score) & & & -0.062 & $0.147 *$ \\
\hline \multicolumn{5}{|c|}{ Level of education (ref $=$ max. primary } \\
\hline Lower vocational & & & $\begin{array}{l}-0.034 \\
-0.211\end{array}$ & $0.801 * * *$ \\
\hline Higher vocational & & & -0.203 & $0.864 * * *$ \\
\hline University & & & & \\
\hline \multicolumn{5}{|l|}{ Tenure $(\mathrm{ref}=\mathrm{rented})$} \\
\hline owner occupied & & & 0.077 & -0.192 \\
\hline \multicolumn{5}{|l|}{ Period $(\mathrm{ref}=2000-2002)$} \\
\hline $2004-2006$ & & & $0.293 * * *$ & 0.028 \\
\hline Constant & $-2.491 * * *$ & $-1.590 * * *$ & $2.199 * * *$ & $1.817 * * *$ \\
\hline & \multicolumn{2}{|c|}{$\begin{array}{l}\text { Initial }-2 L L=3712.6 C h i^{2}=106.5 ; d f=8 ; \\
\text { Sig. }=0.000 ; \text { Nagelkerke's } \mathrm{R}^{2}=0.032\end{array}$} & \multicolumn{2}{|c|}{$\begin{array}{l}\text { Initial }-2 L L=3712.6 C^{2} i^{2}=551.7 ; d f=22 \\
\text { Sig. }=0.000 ; \text { Nagelkerke's } R^{2}=0.197\end{array}$} \\
\hline
\end{tabular}

$0.10 ; * *=p<0.05 ; * * *=p<0.01$

Source: Housing Demand Survey 2002, CBS/VROM; Housing Research Netherlands 2006, VROM 
Table 8: $\quad$ Multinomial logistic regression analysis of residential mobility out of non-concentration neighbourhoods

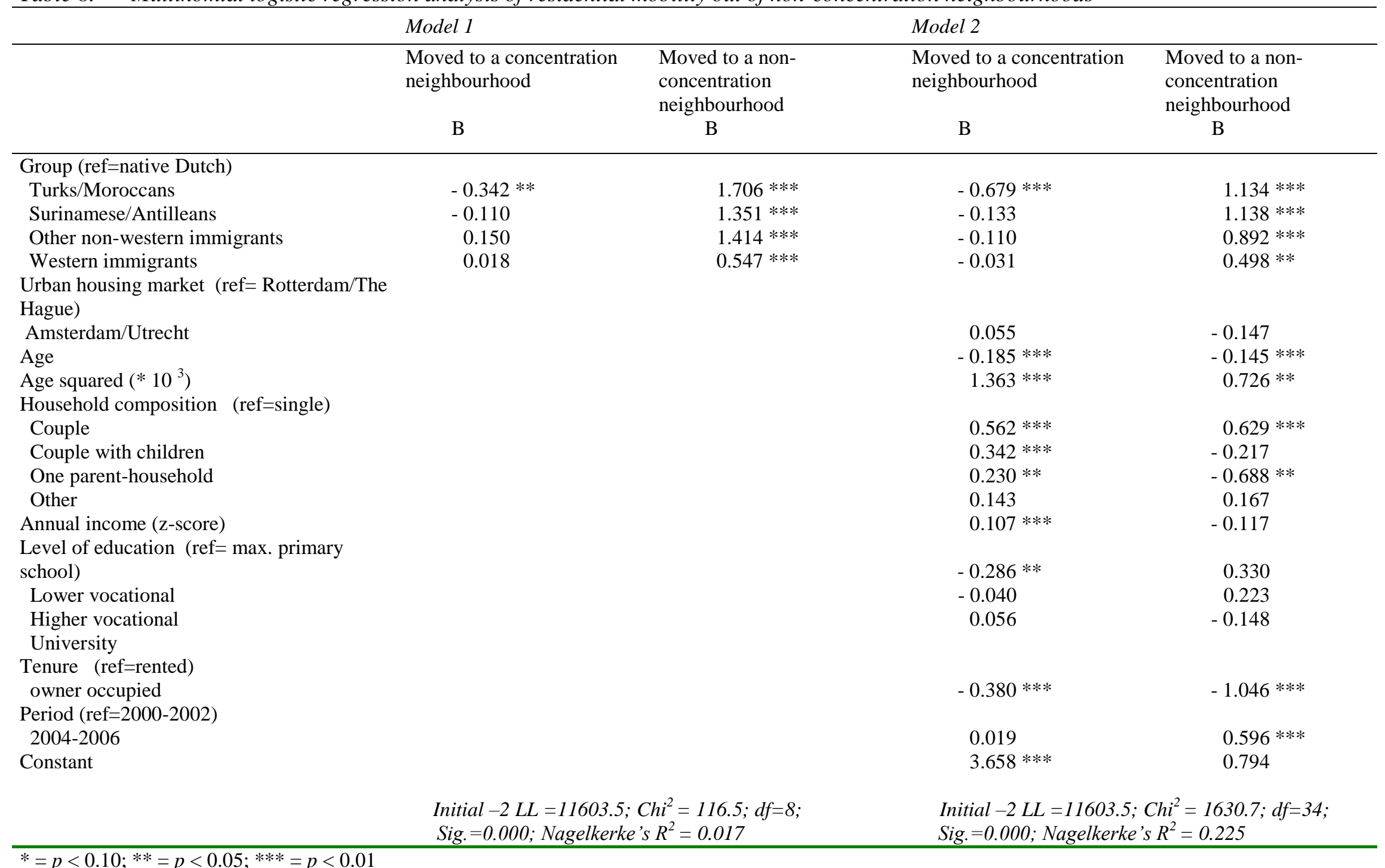

Source: Housing Demand Survey 2002, CBS/VROM; Housing Research Netherlands 2006, VROM 
Table 9: $\quad$ Reaction to statements about the neighbourhood by ethnicity and neighbourhood type

\begin{tabular}{|c|c|c|c|c|c|}
\hline & \multicolumn{3}{|c|}{$\%$ non-western minorities: } & & \multirow{2}{*}{$\begin{array}{r}\text { Kendall's } \\
\text { Tau-c }\end{array}$} \\
\hline & $0-10 \%$ & $10-25 \%$ & $25-50 \%$ & $50-100 \%$ & \\
\hline \multicolumn{6}{|c|}{$\%$ that is satisfied with the population composition } \\
\hline Native Dutch & 87.1 & 78.6 & 61.4 & 48.0 & $-0.220 * *$ \\
\hline Surinamese/Antillians & 94.6 & 79.7 & 74.0 & 60.5 & $-0.151 * *$ \\
\hline Turks/Moroccans & 73.9 & 79.0 & 70.5 & 64.3 & $-0.084 * *$ \\
\hline Other non-western immigrants & 75.4 & 82.2 & 69.8 & 61.4 & $-0.124 * *$ \\
\hline Western immigrants & 85.2 & 78.3 & 67.1 & 52.4 & $-0.183 * *$ \\
\hline \multicolumn{6}{|c|}{$\begin{array}{l}\% \text { that states to have a lot of social contacts with other people in the } \\
\text { neighbourhood }\end{array}$} \\
\hline Native Dutch & 40.3 & 38.0 & 33.2 & 33.3 & $-0.063 * *$ \\
\hline Surinamese/Antillians & 37.5 & 40.5 & 36.3 & 35.7 & -0.029 \\
\hline Turks/Moroccans & 43.5 & 46.3 & 42.0 & 44.5 & 0.016 \\
\hline Other non-western immigrants & 37.7 & 38.1 & 29.0 & 29.2 & $-0.076 *$ \\
\hline Western immigrants & 41.3 & 35.3 & 32.7 & 32.6 & $-0.051 *$ \\
\hline \multicolumn{6}{|c|}{$\%$ that wants to move out of the neighbourhood } \\
\hline Native Dutch & 13.6 & 19.8 & 26.8 & 30.9 & $0.117 * *$ \\
\hline Surinamese/Antillians & 23.2 & 22.9 & 28.4 & 33.8 & $0.079 *$ \\
\hline Turks/Moroccans & 39.1 & 28.4 & 33.0 & 37.3 & 0.034 \\
\hline Other non-western immigrants & 31.9 & 30.2 & 32.4 & 33.6 & $0.065 *$ \\
\hline Western immigrants & 16.8 & 24.4 & 28.4 & 32.6 & $0.118 * *$ \\
\hline
\end{tabular}

$* *=\mathrm{p}<0,01 ; *=\mathrm{p}<0,05$

Source: Housing Demand Survey 2002, CBS/VROM; Housing Research Netherlands 2006, VROM 